\title{
The Idea of Eternal Country in the First Epic Poems of the Turkic People
}

\author{
Aslan E. Alimbayev', Laura N. Daurenbekova ${ }^{2}$, Kayrbek R. Kemenger ${ }^{1}$, \\ Saule K. Imanberdiyeva ${ }^{3}$ \& Nurbol K. Bashirov ${ }^{1}$ \\ ${ }^{1}$ Department of Kazakh Literature, L.N. Gumilyov Eurasian National University, Nur- \\ Sultan, Republic of Kazakhstan \\ ${ }^{2}$ Department of Kazakh and Russian Philology, Eurasian Humanities Institute, Nur-Sultan, \\ Republic of Kazakhstan \\ ${ }^{3}$ Department of Kazakh and Russian Language, S. Seifullin Kazakh Agrotechnical \\ University, Nur-Sultan, Republic of Kazakhstan
}

\begin{abstract}
The inscriptions on the white stones have been evidence of the fact that Turkic people had their writing, culture, tradition, history and the path they made and in the V-VIII centuries. The article introduces with the data about Turkic people inhabited in Central Asia through Orkhon monuments and determines that the ancient Turks struggled to be "an eternal independent country" in the fifth century. Moreover, the article considers the importance of runic inscriptions in the Orkhon monuments in the systematization of Turkic studies by defining the historical-comparative direction of modern linguistics.
\end{abstract}

Keywords: Turkic, translation, transcript, stone inscription, epic poem, toponymy.

\section{Introduction}

Kazakh people became known in the history as the Turkic in the V-VI century. Ancient history of Turkic people emerged in the III century BC and covers the period of the formation of empire of the ancient Huns, and the ninth century AD. Once you become a country, it is clear that you have a unique tradition, culture, and writing.

"Turkic-speaking people and their languages have a very ancient written tradition dating back to at least the turn of our era"(Amanzholov, 1998). That is, the inscriptions on the white stones can be evidence that the Turkic people have had their writing and culture in the V-VIII centuries. From these inscriptions one can learn that the ancient Turkic people aimed at protecting their land from external enemies and becoming an eternal and independent country. For example, "Orkhon monuments" which disclose the mystery of Turkic people of the VII-VIII century are devoted to the heroic actions of the famous heroes Bilge kagan, Kultegin and Tonikok.

In 1893 Danish scientist, who knew many languages $\mathrm{V}$. Thomsen paid attention to the inscriptions on orkhon monuments found in northern Mongolia for the first time and identified

\footnotetext{
(c) AesthetixMS 2020. This Open Access article is published under a Creative Commons Attribution Non-Commercial 4.o International License (http://creativecommons.org/licenses/by-nc/4.o/), which permits non-commercial re-use, distribution, and reproduction in any medium, provided the original work is properly cited. For citation use the DOI. For commercial re-use, please contact editor@rupkatha.com.
} 
the alphabet on the stone. In 1893 the Russian scientist V. Radlov translated the text through the alphabet identified by the Danish scientist V. Thomsen into Russian. S.E. Malov writes about the ancient Turkic inscriptions suggesting that these monuments would be useful in studying the language of the Turkic people: "V.V. Radlov, taking advantage of the discovery of V. Thomsen, first gave the translation of these large inscriptions. Monument on the bank of Orkhon discovered by N.M. Yadrintsev, was put in honor of the Turkic Kagan Mogilian (died in 734) and his brother Prince Kultegin (died in 732). Thus, a new source was found for the history of the nomadic states, which had previously only been drawn from Chinese chronicles. But mainly they are valuable for us from their language material" (Malov, 1951).

V.V. Radlov, P.M. Meloryansky, S.E. Malov proposed the text in Russian in the form of a line, prosa; I. Stebleva gave it in the form of poetry. Meanwhile, the inscriptions on the monuments have been of interest to other scientists and they have been translated into many languages and they start exploring them. For example, turkologist H. Orkun translated and transcribed in Turkish (Orkun, 1994). T. Tekin also translated them into English and gave their transcripts. (Tekin, 1968). Language A. Amanzholov, G. Aidarov translated into Kazakh and gave transcriptions (Aidarov, 1996). Currently, M. Zholdasbekov, K. Sartkozhauly, K. Myrzali and N.G. Shaimerdenov's translation versions of these monuments in Kazakh are being used.

According to scholars' investigation the Orkhon monuments are common to current Turkic people who belonged to the Turkic Kaganate: Kazakh, Kyrgyz, Uzbek, Uyghur, Tatar, Azerbaijan, Turkmen, Altai, Khakas, Karakalpak, Bashkir, Chuvash and Oirats. In the 5th-8th centuries, these peoples were named as the family tribes of Scythian, Eusk, Kangly, Dulat, Oguz and Kipchak who resided the present Central Asia, the Edil region and the Caspian coasts: "From the $5^{\text {th }}$ century the common Turkic language which is understandable for all these family tribes has formed. Turkic people with "long spear and racing horse", who covered the whole Siberya, contemporary Kazakhstan and Central Asia, have survived indescribable disaster and destructive wars for three centuries $(6,7,8$, centuries) in the vast steppe"(Kyraubaeva, 2001).

The ethnonym "Turk" was originally derived from the name of a certain person from a conservative or military aristocracy. "Later, the word semantics gradually increased, becoming a symbol of power, dominant, a symbol of the "king" tribe. In the meanwhile, the tribes who became subordinate to the ruling tribe were also called Turks" (Kelimbetov, 1991).In addition to the inscription on the stones, which are examples of the vast majority of cases it is clear to find out from Iran, Persia, China written data. A literary scholar A. Kyraubaeva: "Kazakh ancestors are Turks, Huns, and Saks. We are dealing with the culture they left. Before the period of foundation of the Kazakh Khanate (XV century), we were called Turks by common name. Because we worship the Sky God, and we spread out from the Blue Wolf, we have become the Blue Turks". (Kyraubaeva, 2001: 232).

It is necessary to study the nature of storytelling and character of the ancient Turkic literature versus systematically. In general, in the field of Kazakh philology science well-known literary scholars and linguists A. Amanzholov (1998). G. Aidarov (1996), M. Zholdasbekov (2012), N. Kelimbetov (2014), A. Kyraubaeva (2001), B. Kenzhebaev (2014) and others wrote many scientific works. The heroic epics created by Saks, Huns and Turkic Khanate era are: "AltynEr Tonga”, "Chu”, "Attila”, "KokBory”, "Ergenekon", "Kultegin”, "Tonikok" and others. Some of these epics have been written clearly on the monuments. These are the books written on the stone. This article refers to the monuments erected to the heroes and khans of the ancient Turkic people, who showed heroism in these wars. 


\section{Methodology}

Reading, transcribing and translating the stone inscriptions are not easy. However, the Orkhon monuments that are of interest to a number of scientists are being studied. In the process of writing a scientific article, the "Orkhon monuments" were taken into account and the historicalcomparative, functional and comparative analysis methods were used to achieve the goals and objectives. The works of scholars who transcribed, translated the texts on the stones have been analyzed, compared, systematized, summarized and concluded.

Turkologist scholars called the inscriptions on the monument rune writing. Rune means "secret" or "unknown". The stone images and monuments prove that ancient rune inscriptions were used on the territory of Kazakhstan during the VII-IX centuries. The inscriptions have been the first alphabet used by the ancient Turkic people. Professor Meloryansky (Meloryansky, 1899) stated that "These inscriptions were able to compensate for the demands and needs of the Turkic tribes, and gave the exact sound features of the Turkic tribes' language". There are also controversial statements among the Turkologists on the origin of the Orhon alphabet. For example, V. Thomsen (1982), W. Radlov (1904), P. Melioransky (1899) noted that the letters in the Orkhon monuments emerged from the Aramaic, but V. Radlov (1904), claimed that these letters came from the west.

V. Radlov (1904), claimed that there are dialectic features in the language of monuments, and he belongs to names ancient Turkic languages to the northern ancient dialect, Uyghur language to the southern ancient dialect, western and eastern ancient Turkic languages to mixed dialects. However, these inscriptions are currently called an ancient Turkic inscription in Turkology. It was challenging for scientists to define the inscriptions from the point of genre. Some people considered as a song, other people thought as a prose, memoirs or even genealogy. In this work, we draw attention to the content and structure of the inscriptions on the Orkhon monuments and prove that the Turkic peoples are the first epic poem.

Comparing the translation and transcript in Kazakh, Russian of the texts of the Orkhon monuments, we paid attention to the author's purpose, idea and chosen genre. We focused on the characteristic sophistication, style and linguistic usage.

\section{Results and Discussion}

Monuments of the ancient Turkic writing were mostly found in Central Asia. The most prominent among them are the stone inscriptions found on the Orkhon, Selenga, and Tolu rivers in northern Mongolia. These inscriptions were called orkhon monuments. These stones inform about the heroism of the hero Kultegin, adviser Tonikok and famous Turkic ruler Bilge Kagan. We will start considering from Kultegin stone. The monument was erected near ErdeniTsu religious house along the Orkhon River in the territory of Mongolia.

The height of the monument is 3.15 meters, width is 1.34 meters and thickness is 0.41 meters. The inscription tells about Kultegin hero and his heroic actions for his people. One of the two monuments placed in the grave of Kultegin is called "a small writing" and the other is "bigger writing". The author of these two poems is the most gifted poet of his time, outstanding public figure Yolligtegin (8th century) (Kelimbetov, 2014). Plots of small writing and bigger writing complete each other. The bigger inscription of "Kultegin" was made up of 40 lines, and smaller one consists of 13 lines. In the poem from beginning to the end Kultegin's courage is described. According to the study of the historians Kultegin lived in the years of 684-731. He was amilitary 
commander of the ancient Turkic Kaganate. His father, Kutlugu served as akagan. After his father's death, Kultegin's brother Bilge was appointed as a kagan.

According to the Chinese data is known as Bilge kaganwas given as Mogilian. He ruled from 717 to 734 . We know from the "Bilge Kagan" monument that the Turkic Khanate was a great empire during Bilge Kagan. The author of the son of Bilge Kagan, Yolligtegin was is the author of Kultegin inscription. The purpose of his action was to leave traditions and history of the Turkic people forever on the stones. The monument tells about the role of Kultegin, the companion of the ruler of Bilge Kagan in the Turkic Kaganate strengthening. The Russian scholar I.B. Stebleva, who researched Orkhon monuments in detail said: "It is poetic, not only in terms of content and shape, but also on rhythm", he said. Stebleva (1965).Consequently, the scientist interprets the stone as a poetic work. A well-known Turkologist L.N. Gumilyov disagreed that "these writings could not be classified as poetic, because we could not find the rhythm required for poetry" (Gumilyov, 1967). L. Gumilyov might pay attention that Orkhon's poems were not only in poetic form, but also some lines of them were in prosaic form. One of the peculiarities of the Kazakh epic poems is the fact that the poet begins to give information about him before describing the main story of the poet. We find this approach in the beginning of the song "Tonikok".

"Bilge Tonikok, I was raised in my native tabgash country. The Turkic people (at that time) were subject to tabgashs". As we observe in this sentence, there is no rhythm of poetry, the author explains about himself in the prosaic form. This is called the method of epic interpretation in the theory of literature. Consequently, the mixing of poems and prosa is a typical example of the subsequent Turkic epic style. According to the findings of Academician A. Margulan, "The Kazakh epic is mainly associated with the events of the past family - household situations, and tribal relations" (Margulan, 1985). If we base on his definitions inscriptions on Orkhon monuments are the starting points of the Kazakh epic. Let's take a look at the following opinion of the academician Kazhym Zhumaliyev: "Today's long epic Kazakh poems started during the patriarchal tribal period: in the time of yisin, kangly, konirat, kerey and kipchaks when each tribe created short poems about their actions" (Zhumaliev, 1958). At present, Kultegin's writing is being taught in Kazakh literature as epic poetry. The 16-year-old Kultegin's heroic deeds to the end of his life have been described in the poem. Turkic people with "long spear and racing horse", who covered the whole Siberya, contemporary Kazakhstan and Central Asia, have survived indescribable disaster and destructive wars for three centuries $(6,7,8$, centuries) in the vast steppe (Amanzholov, 1996).

The Turks have fought with tabgach people many times. "Tabyač>tabgach". "Tougash // Tabgash". The modern name is Chinese. In the IV-VI centuries AD "Tabgachs // tobas" were a nomadic ethnos who governed the state of northern "Chinese" Wei (386-534). After the complete acquisition with China, the ancient Turks called the whole "Chinese" tabgach. Similarly, the word "Chinese // China" was also the name of a semi-nomadic ethnos who regards the settled "Chinese" (Ancient Turkic Monuments, 2017).The Turkic Khaganate, which fought with the Chinese Empire at the end of VII century, was defeated. Later, Kutlyk led the Kagan back to China and conquered the land. Kutlykkagan, who united the Turkic people, died in 693. In the year 716 when Kagan's two sons Bilge and Kultegin grew up, Bilge was appointed as Kagan, Kultegin - was appointed as a military commander. The sequence of compositions of the small inscription and the big inscription of "Kultegin" is preserved. The Kultegin (small writing) poem is composed of eight chapters; each of them was closely related to one another. Each section is a story according to the content. Its first part started with kagan's message to his people. Its transcription:

Теңрі тег, теңрі йаратмыш. 
5 | The Idea of Eternal Country in the First Epic Poems of the Turkic People

Түрк Білге қаған,

Бұ өдке олуртым.

Сабымын түгеті есідгіл:

Улайу інійігүнім, оғланым,

Бірікі оғушым, будунум,

Берійе-шад-апыт беглер,

Йырайа - тарқат буйрук беглер,

Отуз.

(Zholdasbekov, 2012)

In Russian: "Небоподобный, неборождённый (собств. «на небе» или «из неба возникший») тюркский каган, я нынче сел (на царство). Речь мою полностью выслушайте (вы), идущие за мною мои младшие родичи и молодёжь (вы), союзные мои племена и народы; (вы, стоящие) справа начальники шад и апа, (вы, стоящие) слева начальники: тарханы и приказные, (вы) тридцать...”(Malov, 1951: 181). In Kazakh:

Тәңірідей тәңірден жаралған

Түрк Білге қаған

Бұл шақта отырдым.

Сөзімді түгел естіңдер:

Бүкіл жеткіншегім, ұланым,

Біріккен әулетім, халқым,

Оңымда шад, апа бектер

Соламда - тархан, бұйрық бектер

Отыз.

(Zholdasbekov, 2012)

This verse does nothavethe same number of lines or the same rhythm, but one cannot say that it is not exactly the same.The images in the content and word style are the same.In this verse there is a message addressed to the descendants of Turkic people. In the second section one depicts the vast expanse of the territory resided by Turkic kagan. Its transcription:

Ілгерү - күн тоғсыққа,

Бергерү - күн ортусыңару,

Құрығару - күн батсықыңа.

Иырғару - түн ортусыңару

Анта ічрекі будун қоп маңа

Көрүр, анча будун

Көрүр, анча будун.

In Russian: “Впереди, к солнечному восходу, справа, (в стране) полуденной, назади, к солнечному закату, слева, (в стране) полночной, - (повсюду) там (т.е. в этих пределах) живущие (букв. находящиеся внутри) народы - все мне подвластны; столь много народов я всех устроил". In Kazakh:

Ілгері - күн шығысында,

Оң жақта - күн ортасында

Кейін күн батысында,

Сол жақта - түн ортасында

Осының ішіндегі халықтың бәрі

Маған қарайды, халықты 


\section{Осынша көп еттім.}

These lines are intended to tell that the territory of the Turkic countryis large and its population is huge. The poem is devoted to Bilge Kagan's mastering skill of ruling the country and Kultegin'smilitary campaigns. The poem informs us about Elteriskagan, Kapagankagan, and Bilge kagan. After the death of BumynKagan and Istemikagan the Turkic people began to disintegrate and the Turkic Empire began to collapse. During this period, the poem says: "The sons of Tabghash were slaves, and the virgin daughters became female slaves" (made slaves and female slaves).In order to make Turkic nation liberate from the enemy Oguz, Sogdy, Turgesh and Tabgashs the poem depicts Kultegin hero's 23 campaigns. He defeated opponents and settled peace in the Turkic country. The poet proudly declares About Kultegin's feat:

He made the head and the knee bend down,

He made poor people rich.

He made the small number of people to more people

He has done many good things for his country.

Turkic monuments are full of toponymic names. These names contribute to make the definite conclusions about the history and life of the descendants of those who lived in that region. There are about thirty toponyms, ten country and tribe names in Kultegin monument. Most of these toponyms are repeated in the monuments of Bilge kagan and Tonikok. Through the names we can learn about the territory of the Turkic people, about their military campaigns: "The monument contains much information about people resided on the eastern, western, northern, southern sides, about the cities and settlements, and their residents. All this allowed the Sogdians and Chinese to expand their geographical knowledge. Medieval Chinese geographers and travelers received the geographical names and ethnonyms of Central Asia directly from the Turks". (Kenzheakhmet, 2009).

For example, in the poem "Kultegin" there was information about the place Otiken. Some reports suggest that Otiken was the capital of the Turkic peoples. In the small letter "Kultegin",

Nine Oguz clans, people,

Listen carefully to this message.

Deep philosophy

Forward - in the east,

On the right - in the middle of the sun

Later - in the sunset,

On the left - midnight

All this whole nation

Look at me

I made them more.

If you are currently living in Otiken, then people are not sad (Zholdasbekov, 2012). Therefore, the idea behind the Kultegin poems is that there is a search for a resettlement, joy, and happiness. The main idea of "Kultegin" poem is to show the struggle of the Turkic people to be the eternal enemy for the eternal country. We can say that the Turkic people were urged to remain united and become an independent country. Kultegin was called a man when he was 10 years old. At the age of 16, he was fighting against the Tabgash, and he dies at the age of 47 . When Kultegin Batyr died, the whole Turkic people became very sad. It is reported that many famous ambassadors, heroes, craftsmen, and cobblers have come to bury the hero. There is a clear 
7 | The Idea of Eternal Country in the First Epic Poems of the Turkic People

indication that strong masters have been involved in building a monument, decorating it and writing on the stone.

The idea of "Kultegin" poem, which sang the inner unity of the Turkic peoples, coincides in line with the "Tonikok" song. The artistic level of these poems is also high. The song "Tonikok" contains 313 poems. According to Turkologists, the monument consists of 62 runic columns. There are 14 events in the poem. The compositional integrity of the poem is preserved. Tonikok, who was a poet and warrior and advisor for the known leaders of the Turkic Khanate: Elderis, Kapagan, Bilge kagans was "a political leader of the Turkish army". It was clearly depicted in the poem that Tonikok was born and educated in Tabgash (China). Written in VIII century, the song "Tonikok" starts with his self-introduction:

"Bilge Tonikok, I was brought up in the country. At that time Turkic people were dependent to tabgashs"

Consequently, being in China Tonikok and seeing all the violence from China to Turkic people Tonikokjoined Kutilik in 683 and rose up against the Chinese. This time, the Turkic people won, and the Second East Turkic Khanate was founded and Kutilik was elected as "kagan". They defeated the Oguzs, who were raided by tabgashs and thanks to the idea of Tonikok all captives from returned back to their homeland. Tonikok told to Oguzs "We are the closest relatives. There is no other benefit from fighting against each other. The Tabgash nation is our common enemy. Thus we should unite against them. Where do we find ourselves after we have touched each other? Let us be together, tell them about it. Whoever would lie to raise the flag and fight against the enemy, let them come to Otiken". After these words, the Oguz people are gathered under the Turkish flag. Then Tonikok wrote on a stone himself: "After that, the Oguzs came with their feet. I made them come" he remembered that moment with gratitude.

After the death of Kutilik Kagan, his brother Kapagan was replaced. Tonikok served as a reliable companion and a wise counselor. However, one described Kapagan as a cruel kagan and became foolish. There was a disagreement among the tribes and they fought with each other. Kapagan was jealous for Tonikok's authority and he began to isolate him from ruling the country.Kaganatstarted falling. Finally, Kapagankagan died in the hands of his relatives. After the death of Kapagankagan, Bilge (Mogilian) was given a throne. Bilge Kagan restored the tribes that were scattered during the Kapaganperiod and restored the Turkic Kaganate. N.I Yadrintsev found Kultegin's brother Bilge Kagan's (Mogilan) stone by the river Orkhon in Mongolia in 1889. The events on the stone coincide with Kultegin's monument. Bilge Kagan, who made a significant contribution to the strengthening of the Turkic Kaganate, was born in 683 and died in 734. This stone contains 80 lines, over 3000 words, and about 10,000 sign letters. E.L. Klements first discovered the monument and introduced to the public. V.V. Radlov made a translation of the monument and published it in German.

Bilge kagan was the famous ruler of the second Eastern Turkic Khaganate. The word "bilge kagan" means "qualified, competent, capable kagan". During the power of Bilge Kagan the Second Turkic Khaganate became a powerful empire. The poem also has the idea of preserving the country's integrity. In the Bilge Kagan Monument there are clear data about nomadic Turkis ethnics such asOguz, Nine-Oguz, Kyrghyz, Korikan, thirty Tatars, Tattaby, Kithan, Uyghur, three Kurikan, Karluk, Turgesh, and Mongolian-Manjur tribes, and the Bokuli desert country, tuput, apar, purum, tabgash, and other settled countries.

Bilge Kagan relies on his brother Kultegin and elects him as the army chief. He appointed Tonikok as a state advisor. According to historical data, during the twenty years of Bilge Kagan 
peaceful life between China and two countries were restored. The poem does not tell about Bilge Kagan, but also the heroism of Kultegin and Tonikokon the way of preserving the country.

"God is blessed!

All Turkic people

I did not let an armed attack,

I did not make the army come.

If Elteris does not conquer kagan,

If I didn't accompany him and did not fight him,

my nation, my people would be destroyed.

As a result of his attack,

as a result of my attack

the country became a country again,

Our people were a nation again.

I was old and I was great.

To the land of Turkic Bilge kagan

He wrote down on the stone

I'm Bilge Tonikok" says a wise old man.

Historical records show that Tonikok died in 741 at the age of 95 and Bilge Kagan died in 734 from poisoning. We belong to epic poems the inscriptions on Orkhon monuments that describe the ancient leaders of Turkic people and heroes of the country. The reason is that the poetry is written in poetic method, and it enhances the poetic outline of the work. The Turkic states were able to withstand their own defense and onslaught on competitiveness between major countries at the turn of the century. It is well written in the history that no great enemy of the Great Turkic Kaganate could defeat the army. However, the enemy of the Turkic country, which has been fierce, has been aggressive for centuries. Finally, the Great Turkic Empire is divided into two parts. These difficult times were also described in poems. However, it illustrates the country's poor state in order to shift the people's hopes.

Wise men, brave men

Tabgashs could not move

Intelligent people and brave people.

If a person is deceived,

No people would have survived.

Much deceived

Sweet word, noble world.

Turkic people have been deceased,

Turkic people have been destroyed,

Dreamt on staying beyond Chugai hollow,

It was desirable in the plains at night,

Turkic people have been destroyed...

(Zholdasbekov, 2012: 349)

It is possible to understand that the Turkic people would be preserved thanks to clever and brave leaders. The poems written in order to strengthen people's desire started from these periods. The legends of the Stone Age, Persian and Chinese data depicted the period of great and competitive Turkic country. We believe that this is done because they intended to show the future generations the result of descendant's' accomplishments and their path through eternal stones. We can see this in the following lines of the "Kultegin" poem: 
God At the height,

Below, when the earth is formed,

When a human is born between them.

I'm a human being and I came from Buminkagan, Istemikagan was ruling.

Formed and owned Turkic people

The four corners were all enemies,

With the soldiers,

People in four corners

He made everything peaceful,

He made the head and the knee bend down,

Prior to the Kadyrkanhollow,

Covered up to the Iron Gate

(Zholdasbekov, 2012: 352).

Ancient Turks have implemented the geopolitical, internal and external defense frameworks of the Turkic people, which provide security for the country. That idea became the main motto of today's Kazakh nation.

\section{Conclusions}

It is not necessary for any nation to have the early literature or the versions of the literature in the modern language of the same population. It is possible that the variants of the literature could describe the life of those people during that period, but it is in other languages, and they are incomprehensible to those people today, although they are done by those people the scientist said.

That is why the inscriptions on the Orkhon monuments written in ancient Turkic, Chagatai (Chagatai, the language of the Turkish tribes, mixed with the Arabic and Persian words, which was understood by all the Turkic people of the time), in Uighur, Arabic and Persian languages we consider as the beginning of history of our literature. The works of our ancient literature are not merely the part of the Kazakh people, but also their literature of other Turkic people. It is because Kazakh people lived together with Uzbek, Kyrgyz, Azerbaijan, Turkmen, Uyghur, Karakalpak, Khakas, Bashkir and Tatar tribes. They lived in the territory of contemporary Kazakhstan, Central Asia, South-Eastern Siberia, Central Asia, the Volga, and the Caspian Sea. As the economic, social and cultural life was closely interconnected, it is clear that the literature of the Turkic-speaking people is common. Kurds, Desert Kipchaks, and other half-nomadic, halfsettled Turkic-speaking people's courage, lifestyle, and desire are depicted in poetic way and described in heroic epics, fairy tales and legends. They left their praising or mourning the loss of the most their significant historical figures on the gravestones or dome-shaped monuments. This indicates that the writing culture of the Turkic people emerged from the ancient time.

These inscriptions were based on preservation of works of medieval writers such as Kultegin, Tonikok, Korkyt Ata, Yusuf Balasaguni, Mahmud Kashgari, Ahmet Yasawi, Baqghani, Khorezmi and others. We can see from these works that ancient Turkic nation lived in peace and the country was prosperous from both external and internal sides. The peaceful way of life begins with the ancestors of the Turkic people, i.e. from Saks period, and the Kazakh people continue it with the idea of "Eternal country". The idea of "Eternal country" was adopted and announced when all Turkic people lived under one roof in the seventh century Thus, this idea, which has 
been verified through history, is common to the whole Turkic world, and joining around this ideology is dream of today's Turkic people.

\section{Recommendation}

The poems written on the stones remaining from the Turkic tribes have become the common heritage of the Turkic people today as a treasure of the history of the social, cultural and literary life of the ancient epoch. Runic monuments are a valuable treasure of the Turkic peoples that proves that the cultural level of the ancient times was very high. Scientifically comprehensive and systematic study of the ethnos and statehood, language and graphic system (records), historicalcultural and ethno-political situation of the Kazakh and other Turkic peoples is a huge challenge to the Turkic peoples. In this regard, the first President of the Republic of Kazakhstan N.A. Nazarbayev on October 3, 2009, at the IX Summit of Heads of Turkic Speaking States in Nakhchivan city located in Azerbaizhan proposed to consider the place of Turkic civilization in the universal civilization and to establish an international scientific center for studying the past, present and future of the Turkic world. The proposal was supported by the Turkic-speaking states, and on May 25, 2010 the scientific center - the Turkic Academy was opened in the capital of the Republic of Kazakhstan - Astana. The goal of the International Turkic Academy is to support the development of science and education in the scientific community of Turkic people as well as to support the initiatives of other Turkic-speaking states. Under the leadership of the Turkic Academy it is necessary to carry out the following work on the propaganda of the literature and the language of the Turkic people:

Firstly, studying the history of the Turkic world from the ancient times; Secondly, the publication of books, comparing the similarities and differences of traditions of contemporary Turkic people; Thirdly, the study of the language, literature and culture of the Turkic people based on specific monuments and the contribution of the Turkic states to the world civilization and publishing the works in the English and Russian languages;

Fourthly, every year the Turkic Academy needs to organize a symposium of the international Turkic world studies. Fifthly, it is necessary to study the disciplines "Literature of Turkic people", "Language of Turkic people" at the faculties of philology. In general, it is necessary to strengthen the development of scientific and humanitarian integration between the Turkicspeaking states. It is obvious that historical ties and unity of the contemporary Turkic people can be strengthened and important for the common culture of Turkic nations.

\section{References}

Aidarov, G. (1996). Monument of Kultegin. Almaty: Writer.

Amanzholov, A. (1996). Turkic philology and writing history. Almaty: Sanat.

Amanzholov, A. (1998). Inscriptions of Orkhon Monuments. Almaty: KSFLP.

Ancient Turkic Monuments. (2017). Retrieved from http://atalarmirasi.org/257-kone-turk-zhazbaeskertkishterinde-atalatyn-shetel-etnonimderi)

Gumilyov, L.N. (1967). Ancient Turks. Moscow: Nauka.

Kelimbetov, N. (1991). Literature of ancient period. Almaty: Ana Tili.

Kelimbetov, N. (2014). Research studies about ancient Turkic literature. Almaty: Writer.

Kenzheakhmet, N. (2009). Toponyms in ancient Turkic (Orkhon) monuments. Izvestiya NAN RK, Series of Public Science, 257-267. 
11 The Idea of Eternal Country in the First Epic Poems of the Turkic People

Kenzhebaev, B. (2014). Ancient Turkic Literature Studies. Almaty: Writer.

Kyraubaeva, A. (2001). Ancient literature. Astana: Elorda.

Malov, S. (1951). Monuments of ancient writing. Moscow: Publishing House of the Academy of Sciences of the USSR.

Margulan, A.H. (1985). Ancient legends. Almaty: Writer.

Melioransky, P.M. (1899). Monument in honor of Kul-Tegin. Saint-Petersburg: Academy of Science.

Orkun, H. (1994). Old Turkic calligraphy. Ankara: Science.

Radlov, V. (1904). Examples of folk literature of the North Turkic tribes. Michigan: Eastern Literature.

Stebleva, I.V. (1965). Poetry of Turks in VI-VIII centuries. Moscow: USSR Academy of Sciences, Institute of World Literature named after A.M. Gorky.

Tekin, T.A. (1968). Grammar of Orkhon Turkic. Indiana: Bloomincton.

Thomsen, V. (1982). History of studying of Turkic languages in Russia. Moscow: Science.

Zholdasbekov, M. (2012). Precious channels. Volume I. Astana: Kultegin.

Zhumaliev, K. (1958). Problems of Kazakh epic and history of literature. Almaty: Writer. 